\title{
What Do High-Interest Borrowers Do with their Tax Rebate?*
}

\section{Marianne Bertrand}

\author{
Adair Morse
}

\footnotetext{
* Marianne Bertrand: Booth School of Business, University of Chicago, 5807 S. Woodlawn Avenue, Chicago, IL 60637; email: marianne.bertrand@ChicagoBooth.edu; phone: 773-8345943; fax: 773-7020458. Adair Morse (corresponding author): Booth School of Business, University of Chicago, 5807 S. Woodlawn Avenue, Chicago, IL 60637; email: adair.morse@ChicagoBooth.edu; phone: 773-8341615; fax: 773-7020458. Session title: "Rationality in Consumer Credit Markets" (chair: David Laibson). We thank Nava Ashraf, Jonathan Parker, Nick Souleles, the National Poverty Center at the University of Michigan, the Templeton Foundation and the Initiative on Global Markets at the University of Chicago for financial support. Bertrand thanks the Stigler Center of the University of Chicago and Morse, the William Ladany Memorial Faculty Research Fund.
} 
A set of influential papers ${ }^{1}$ find substantial consumption out of tax rebates, with evidence pointing to an important role for liquidity constraints. Sumit Agarwal, Chunlin Liu and Souleles (2007) directly test the importance of liquidity constraints among credit card borrowers receiving rebates; they find that those most likely to be liquidity constrained show the largest increase in credit card spending from the rebate check. The evidence that constrained individuals are big tax rebate spenders is important for fiscal policy but also raises questions about the underlying behavioral responses. In particular, many individuals rely on expensive debt, and the lifetime (time-consistent) utility cost from spending rather than paying off such debt can be quite large. This point is particularly relevant for the group of borrowers we consider in this paper, payday loan customers, for whom the cost of marginal debt is extremely high (paying APRs over $400 \%)^{2}$

Using the natural experiment of the 2008 tax rebate, we find a persistent decline in payday borrowing in the pay cycles that follow the receipt of the tax rebate. The reduction in borrowing is a significant fraction of the mean outstanding loan (12 percent) and appears fairly persistent over the time, but is moderate in dollar magnitude (about \$35) relative to the size of the rebate check ( $\$ 600$ per person). These estimates are likely lower bounds for the causal effect of the tax rebate on debt retirement because of measurement error in the timing of the rebate.

In a next step, we document two sources of heterogeneity in our sample of payday borrowers that offer some clues about marginal uses of income for those who choose not to use the tax rebate to retire their payday debt. First, some would argue that payday borrowers are especially likely to be the types making "mistakes" (or at least exhibiting unique preferences

\footnotetext{
${ }^{1}$ Nicholas S. Souleles (1999); David S. Johnson, Jonathan A. Parker, and Souleles (2006); Christian Broda and Parker (2008).

${ }^{2}$ See Gregory Ellihausen and Edward C. Lawrence (2001), Adair Morse (2007), Paige Marta Skiba and Jeremy

Tobacman (2007), or Brian T. Melzer (2007) for an overview of payday lending.
} 
over time or in purchasing point utility), which may lead them to use their tax rebate for “temptation” consumption rather than for straightening out their financial situation. Consistent with this, we find that individuals mentioning vacations, apparel, entertainment, gifts or electronics as a use for the payday loan or as a large expense item from earlier in the year do not use any of the tax rebate to reduce borrowing. This however does not seem to explain why payday loan borrowers as a whole do not use more of their rebate check to retire debt, as only a small portion (9 percent) of payday loan borrowers fit this category.

Another clear pattern that emerges from our data is that only the low-to-middle users of payday lending services (measured in terms of frequency of use in the prior year) retire debt; this group retires 15-20 percent of their loan balances after receiving the tax rebate. We believe that the effect is concentrated in low-to-middle frequency users because they are the group most likely to be using payday loans to bridge infrequent unexpected gaps between pay days. This group of low-to-middle frequency users of payday loans might map best into the subset of individuals surveyed by Matthew D. Shapiro and Joel B. Slemrod (2003) who self-report to be unable to handle expense shocks without credit; two thirds of these individuals, Shapiro and Slemrod show, said they used the 2001 rebate to pay down debt.

In contrast, high-frequency users of payday loans retire no debt. We cannot find much evidence for high-frequency borrowers being cognitively or educationally more challenged, although we certainly cannot draw a complete behavioral profile. The only consistent pattern we observe about the high-use group is that they are more likely to use payday loans for regular monthly bills (rent, utilities, gasoline, groceries, etc.) than other categories of borrowers. Hence, for this group, the tax rebate might have been used to avoid (or at least postpone) having the gas connection turned off or to catch up with late rent payments. 
I. Data

During the period May 19 - June 14, 2008, we conducted a survey and field experiment with a large national payday lending chain (see Marianne Bertrand and Morse (2008) for more details). For two weeks at each of 70 payday lending stores, we offered every loan customer a year magazine subscription in return for their participation in our study. Participation entailed filling out a one-to-two minute paper survey at the time of borrowing and allowing us to receive a download of their transaction history and application data from the company. We obtained a $21 \%$ participation rate among all customers entering the stores, and the average participant is not materially different (other than being slightly poorer) from the average payday loan borrower described in Ellihausen and Lawrence (2007). In October 2008, the lender provided us with loan transaction history for each of these consenting customers.

An important feature of payday lending is that the borrower's pay cycle frequency determines the loan length, as loans are always due on payday. We balance the panel in time such that if a person does not have an entry at a date implied by their pay cycle, we create one (imputing $\$ 0$ borrowing for that date). To focus our analysis around the IRS payment dates (May - July), we limit the data to being three semi-monthly pay cycles prior to the first IRS check mailing date and three pay cycles after the last check mailing. ${ }^{3}$ The resulting sample period is March 24 - September 12, 2008. We also limit our sample to customers who are recruited into our sample before they receive their rebate check so that entry into the sample is not affected by the rebate money.

The final sample is 881 individuals. The median person in the sample is 42 years old, with a monthly income of $\$ 2,257$. She borrowed $1 / 3^{\text {rd }}$ of the possible pay cycles during the prior

\footnotetext{
${ }^{3}$ Eighty-two percent of the sample is paid either bi-weekly or semi-monthly.
} 
year and paid \$438 in fees over this prior year. Very few payday borrowers in the sample lack a high school degree (5\%) or have a college degree (15\%). Instead, half have had some college, and the residual (29\%) went into the workforce directly after high school. The mean (median) loan in the sample is $\$ 506$ (\$376) conditional on a loan being taken, and \$325 (\$299) including all zero loan observations.

Almost all of our sample would have qualified for the $\$ 600$ per person IRS tax rebate of 2008. We assume that they get the rebate during the IRS check mailing waves rather than via direct deposit. We base this assumption on anecdotal evidence that the majority of payday loan customers take out tax refund anticipation loans, implying that they would not have provided the IRS with their checking account information on their 2007 tax returns (the requirement for getting the rebate via direct deposit). To assess how accurate this assumption is, we asked this question directly in a follow-up phone survey of a small subsample of study participants. Of 97 people who said they had received a tax refund payment, $66 \%$ said they got a check in the mail rather than direct deposit. Although this statistic is reassuring, this also suggests that our results may be biased toward zero.

\section{Econometric Specification}

The IRS mailed checks in nine waves based on social security numbers from May 16 to July 11, 2008. We allow for a minimum of two days in mailing time and create the variable Check $_{i t}$, which is equal to 1 on the first possible borrowing visit (according to the person's pay cycle) to the payday lender after the IRS check issue day for the person's two-digit social security number, and 0 otherwise. We also create variables $C h e c k_{i t-1}$ and $C h e c k_{i t-n}$, which are lagged tax rebate indicators capturing the effect of the check during, respectively, the second 
possible visit to the lender and all subsequent possible visits up until September 12. As in Johnson, Parker and Souleles (2006) and Broda and Parker (2008), the randomness of the last two digits of social security numbers provides exogeneity for identification.

We focus on two main outcome variables $\left(Y_{i t}\right)$. $I_{\text {NotBorrow, it }}$ is a dummy variable that equals 1 if individual $i$ did not borrow in pay cycle $t ; 0$ otherwise. Loan Amount ${ }_{i t}$ is the amount borrowed by individual $i$ during pay cycle $t$; we assign a value of 0 if individual $i$ did not borrow in pay cycle $t$.

The main econometric model we estimate is as follows:

$$
Y_{i t}=a+b^{*} \text { Check }_{i t}+c^{*} \text { Check }_{i t-1}+d^{*} \text { Check }_{i t-n}+\text { Week }_{t}+\text { Ind }_{i}+e_{i t} \text {, }
$$

where Week $_{t}$ is a vector of dummy variables for calendar weeks; Ind $_{i}$ is a vector of individual fixed effects; and $e_{i t}$ is the error term. The econometric model therefore accounts for any calendar effects on the amount of borrowing, as well as any individual-level differences in the level borrowing. The estimated coefficient on Check $k_{i t}$ measures the change in the likelihood of borrowing (or amount borrowed) in the pay cycle in which the IRS check is issued (compared to pre-check level). The estimated coefficients on $C h e c k_{i t-1}$ and $C h e c k_{i t-n}$ respectively measure changes in the likelihood of borrowing (or amount borrowed) in the second and post-second pay cycles after the IRS check is issued (compared to pre-check level); they allow us to gauge persistence in the tax rebate effect. We cluster the error term at the rebate check date level and weight each observation by the inverse of the number of pay cycles for a given individual; this ensures that weekly individuals (who have more cycles in the sample) are not over-represented.

\section{Results}

Table 1 presents our main results. Column 1 shows a statistically significant decline in 
the likelihood of payday borrowing in the first two payday cycles following the issue of the tax rebate check. Payday borrowers are 6 percentage points less likely to take up a payday loan in the pay cycle in which they receive their rebate, and remain 5 percentage points less likely to take up a payday loan in the next pay cycle. A 5-6 percentage point decline is a 14-17 percent change in the ability of individuals to avoid borrowing from the mean $I_{\text {NotBorrow }}$ of 36 percentage points. Two pay cycles or more after receiving the tax rebate, the likelihood of payday borrowing is no longer statistically different from its pre-rebate level. In column 2, we investigate the possibility that individuals might anticipate the receipt of a tax rebate and adjust their borrowing activity prior to actually receiving their check. To do so, we add to the model estimated in column 1 a dummy variable that equals 1 during the pay cycle that immediately precedes the check issue cycle, 0 otherwise. The estimated coefficient on that dummy variable is economically very small (-0.0004) and statistically insignificant. ${ }^{4}$

Table 1

\begin{tabular}{lcccc}
\hline & $I_{\text {NotBorrow }}$ & $I_{\text {NotBorrow }}$ & $\begin{array}{c}\text { Loan } \\
\text { Amount }\end{array}$ & $\begin{array}{c}\text { Loan } \\
\text { Amount }\end{array}$ \\
\hline Check $_{\mathrm{t}+1}$ & & -0.000 & & 2.422 \\
& & {$[0.019]$} & & {$[10.45]$} \\
Check $_{\mathrm{t}}$ & $0.062^{* *}$ & $0.061^{* * *}$ & $-36.24^{* *}$ & $-34.18^{* *}$ \\
& {$[0.020]$} & {$[0.016]$} & {$[10.56]$} & {$[10.44]$} \\
Check $_{\mathrm{t}-1}$ & 0.053 & $0.053^{* *}$ & $-42.29^{* *}$ & $-40.07^{* *}$ \\
& {$[0.028]$} & {$[0.022]$} & {$[12.75]$} & {$[13.83]$} \\
Check $_{\mathrm{t}-\mathrm{n}}$ & 0.015 & 0.014 & -26.26 & $-23.93^{*}$ \\
& {$[0.031]$} & {$[0.022]$} & {$[13.89]$} & {$[11.41]$} \\
Obs & 7987 & 7987 & 7987 & 7987 \\
Individuals & 881 & 881 & 881 & 881 \\
R-squared & 0.119 & 0.119 & 0.096 & 0.096 \\
\hline Individual fixed effects \& week dummy variables included. \\
Standard errors clustered at the IRS wave date. \\
\hline \multicolumn{5}{c}{} \\
\hline \multicolumn{5}{c}{}
\end{tabular}

Columns 3 and 4 replicate columns 1 and 2 but use amount borrowed in the pay cycle as the dependent variable. This allows us to study changes in borrowing activity not only on the extensive margin but also on the intensive margin. We estimate a statistically significant decline

\footnotetext{
${ }^{4}$ Looking further back in time also yields no evidence of ramping up of borrowing prior to the tax rebate date.
} 
in payday borrowing in all the pay cycles that follow the receipt of the tax rebate check. The effect is largest in the first two post-rebate cycles (about a $\$ 40$ decline in borrowing in each of these cycles, compared to a mean loan of \$325); it stays economically meaningful in all following cycles (about a $\$ 25$ decline), or at least for the two-to-three months period covered in our panel. We find no effect of the (anticipated) tax rebate on the amount of borrowing in the pay cycle that immediately precedes the check issue (column 4). ${ }^{5}$

In summary, we find evidence consistent with the view that the average payday borrower in our sample uses (fairly persistently) some of the tax rebate to reduce his or her dependence on payday borrowing. Because we measure the timing of the tax rebate with error (remember that we assume that all individuals in our sample receive rebates in the mail), it is likely that our estimate (about a 12 percent "permanent" decline in the amount of payday borrowing) is a lower bound for the true causal effect of the tax rebate on the retirement of high-interest payday loans.

In magnitude, our estimates of how much debt is retired appear larger than what Agarwal, Liu and Souleles (2007) find for the most constrained credit card borrowers but smaller than what Shapiro and Slemrod's (2003) survey evidence would suggest. To reconcile these findings and shed light on the tensions in spending versus retiring debt decisions, we investigate whether possible sources of heterogeneity across payday borrowers affect their use of the tax rebate.

We first explore the possibility that payday borrowers are just people who love spending and get gratification through immediate consumption. We split the sample on whether or not the person chooses any of vacations, eating out or entertainment, or gifts, apparel or electronics as a

\footnotetext{
${ }^{5}$ We have verified that the results presented in Table 1 are robust to various specification checks. In particular, we estimated an alternative model where we allowed for different time trends in borrowing across the various stores in the sample, to account for the possibility of regional trends in economic activity. We also estimated an alternative model where we allowed for different trends in borrowing based on the specific day at which a given individual was recruited to participate in our primary experiment. Under both of these alternative models, the main effects estimated in Table 1 were economically and statistically unchanged.
} 
use for the loan proceeds in the participation survey. ${ }^{6}$ These choices correspond to Souleles (1999) and Parker (1999) who find a jump in consumption for vacations (Souleles) and entertainment and apparel (Parker) for unconstrained individuals after a tax windfall. About 9 percent of the sample falls into this category. So, this is not a very large group. This in itself is interesting, even though there is some reporting concern (e.g., people that intend to use a payday loan to go on vacation may not be upfront about it). As the first two columns of Table 2 show, temptation spenders sharply contrast with the others in not paying down their payday loans after they receive their tax rebate, neither immediately nor a few cycles out. In fact, the point estimates on all the Check variables are positive, suggesting if anything an increase in borrowing after the rebate check is issued. As a check of the robustness of these findings, we also split a small subsample of the participants whom we reach in a follow-up phone survey based on whether they say that they have had an electronics or vacation large expense item thus far in the year. Although the sample size of individuals is small, those who had large vacations or electronic expenditures do not use the rebate check to pay down debt.

Table 2

\begin{tabular}{|c|c|c|c|c|c|}
\hline & \multicolumn{5}{|c|}{ Dependent Variable: Loan Amount } \\
\hline & \multicolumn{2}{|c|}{$\begin{array}{c}\text { Vacation, Eating } \\
\text { Out/Entertainment or } \\
\text { Gifts, Apparel, or } \\
\text { Electronics } \\
\end{array}$} & \multicolumn{3}{|c|}{ Quartiles of Borrowing Frequency } \\
\hline & $\begin{array}{c}\text { Not Listed } \\
\text { as Use }\end{array}$ & $\begin{array}{c}\text { Listed as } \\
\text { Use }\end{array}$ & 1 & $2 \& 3$ & 4 \\
\hline Check $_{\mathrm{t}}$ & $\begin{array}{c}-42.29 * * * \\
{[12.00]}\end{array}$ & $\begin{array}{c}45.47 \\
{[39.43]}\end{array}$ & $\begin{array}{l}-49.30 * \\
{[25.57]}\end{array}$ & $\begin{array}{c}-45.56^{* *} \\
{[16.74]}\end{array}$ & $\begin{array}{c}-16.80 \\
{[12.64]}\end{array}$ \\
\hline Check $_{\mathrm{t}-1}$ & $\begin{array}{c}-49.49 * * \\
{[14.58]}\end{array}$ & $\begin{array}{c}50.34 \\
{[49.23]}\end{array}$ & $\begin{array}{l}-39.06 \\
{[30.55]}\end{array}$ & $\begin{array}{c}-70.26^{* *} \\
{[21.47]}\end{array}$ & $\begin{array}{c}-16.82 \\
{[28.79]}\end{array}$ \\
\hline Check $_{\mathrm{t}-\mathrm{n}}$ & $\begin{array}{c}-31.74 * \\
{[15.16]}\end{array}$ & $\begin{array}{c}42.85 \\
{[67.04]}\end{array}$ & $\begin{array}{c}-18.85 \\
{[37.05]}\end{array}$ & $\begin{array}{c}-69.11 * * \\
{[26.91]}\end{array}$ & $\begin{array}{c}39.19 \\
{[43.72]}\end{array}$ \\
\hline Obs & 7330 & 657 & 2167 & 3790 & 1938 \\
\hline Individuals & 807 & 74 & 253 & 428 & 203 \\
\hline R-squared & 0.095 & 0.157 & 0.198 & 0.103 & 0.096 \\
\hline
\end{tabular}

\footnotetext{
${ }^{6}$ The other possible choices were rent or mortgage payments, utilities, medical bills, groceries, family emergencies, transportation expenses, other debt and other bills.
} 
Individual fixed effects \& week dummy variables included.

Standard errors clustered at the IRS wave date.

In columns 3-5 of Table 2, we contrast individuals that are high frequency users of payday loans with those that use payday loans with low-to-middle frequency. To proceed, we sum the number of times each individual took out a payday loan in the year preceding the tax rebate and normalize by the number of pay cycles for that individual during the same year. We then categorize individuals into low, middle and high users of payday loans by quartile. The lower quartile frequency users borrow less than $1 / 6^{\text {th }}$ of cycles; the interquartile frequency users borrow between $1 / 6^{\text {th }}$ and $2 / 3^{\text {rds }}$ of possible cycles; and the upper quartile frequency users borrow more than $2 / 3^{\text {rds }}$ of cycles. Columns 3,4 and 5 of Table 2 replicate the estimation in column 3 of Table 1 for the low, middle and high users of payday loans, respectively.

A striking finding is that there is no causal effect of the tax rebate on the tendency to retire payday debt among the high usage groups (column 5). The (negative) causal impact of the rebate on the amount of payday borrowing is largest and most persistent in the middle usage category, reaching a $\$ 60$ to $\$ 70$ persistent effect after the issue of the rebate check. This reduction translates into a 17 to 20 percent decline in borrowing. After taking into account the lower mean borrowing by low frequency borrowers, the results in column 3 suggest that low frequency borrowers reduce their borrowing by about 15 percent.

It might appear quite intuitive that the one-time rebate is most effective at reducing the dependence on payday loans among the more moderate users of those loans, who are presumably more likely to turn to such high-interest borrowing only in the case of unexpected, non-recurrent shocks that create an immediate need for some bridge financing. The one-time tax rebate could offer this group a buffer that would protect them for at least a little while from having to take up another payday loan. Among our payday borrowers, this group may be most comparable to the 
survey respondents in Shapiro and Slemrod (2003) that say they would have to use credit to finance a shock; Shapiro and Slemrod show these people to be the most likely to say they used their 2001 tax rebate to retire debt.

One is left with trying to make sense of the behavior of high usage payday borrowers. We find limited evidence that this group strongly overlaps with the "temptation" spenders. At best, we find a slightly higher share reporting using payday loans to pay for vacation expenses among the high paying fees group, but this pattern does not extend to the other temptation spending categories in the list we constructed. ${ }^{7}$ It is also possible that this group is more educationally challenged, less aware of the high cost of payday borrowing and therefore mistakenly deciding not to use the rebate to pay down their loan. However, using information collected in a small follow-up survey we conducted, we do not find high frequency borrowers to be less aware about the cost of payday loans, either measured in terms of APR or fees.

The most robust systematic difference we find between low-to-middle and high usage borrowers was that high-usage borrowers are more likely to use payday loans to cover regular monthly expenses (such as paying rent, bills, or buying groceries). Hence for this group, payday loans are less a means to adjust to short-term unexpected shocks but more a part of everyday living. We conjecture that this group's marginal use of the tax rebate might have been catching up on past due rent to avoid eviction or paying a late gas bill to avoid a disconnection.

\section{Conclusion}

Using transaction data, we show that payday borrowers used part of their 2008 tax rebate to reduce their level of payday debt. The largest debt reduction comes from middle frequency users

\footnotetext{
${ }^{7}$ There is also some evidence that high usage borrowers score higher on an "enjoy spending” scale included in the participation survey. However, splitting the sample based on this scale does not help explain debt retirement behavior.
} 
of payday loans, who use $\$ 70$ of their stimulus check to retire debt. On average, the low-tomiddle users of payday loans retire 15 to 20 percent of their outstanding payday loans, which probably represents the marginal debt they face. Because of measurement error in the timing of when people receive their rebate, our estimates are likely lower bounds for the causal effect of the rebate on debt retirement. With this caveat in mind, it does appear, consistent with Agrawal, Lui and Souleles (2007), that the amount of the check used by payday loan borrowers to pay down their marginal debt is limited.

In trying to reconcile this finding with the cost of not retiring expensive payday debt, we find substantial heterogeneity across borrowers. Among individuals that we classify as temptation spenders (e.g. those that use $400 \%$ APR loans to buy electronic goods or go on vacation), we find no reduction in payday borrowing after the tax rebate is issued. A second group for which we find no debt retirement post-check is the set of borrowers that appear to use what should be short-term payday loans as a long-term financing solution. We infer that the marginal use of the tax rebate for this group was to deal with regular monthly obligations, such as paying down late utility bills or making rent payments.

We think our results help reconcile the results of Shapiro and Slemrod (2003) with that of Agarwal, Liu and Souleles (2007) in documenting to what extent debt is retired out of a tax rebate shock and in suggesting why more debt may not be retired. Our results also highlight the underlying heterogeneity in the payday borrowing population. To understand individuals' financial decisions, we need a better grasp of the types who end up highly indebted as well as of the exact economic and financial circumstances they face. 


\section{References}

Agarwal, Sumit, Chunlin Liu, and Nicholas S. Souleles. 2007. “The Reaction of Consumer Spending and Debt to Tax Rebates - Evidence from Consumer Credit Data.” Journal of Political Economy, 115(6): 986-1019

Bertrand, Marianne and Adair Morse. 2008. “Financial Literacy, Cognitive Biases and Payday Lending.” Working Paper.

Broda, Christian and Jonathan A. Parker. 2008. “The Impact of the 2008 Economic Stimulus on Consumer Demand.” Working Paper.

Elliehausen, Gregory and Edward C. Lawrence. 2001. "Payday Advance Credit in America: An Analysis of Customer Demand." Georgetown Credit Research Center, Monograph No. 35.

Johnson, David S., Jonathan A. Parker, and Nicholas S. Souleles. 2006. "Household Expenditure and the Income Tax Rebates of 2001.” American Economic Review, 96(5): 1589-1610

Melzer, Brian T. 2007. “The Real Costs of Credit Access: Evidence from the Payday Lending Market.” Working Paper.

Morse, Adair. 2007. “Payday Lenders: Heroes or Villains?” Working Paper.

Parker, Jonathan A. 1999. “The Reaction of Household Consumption to Predictable Changes in Social Security Taxes.” American Economic Review, 89(4):959-973.

Shapiro, Matthew D. and Joel B. Slemrod. 2003. "Consumer Response to Tax Rebates." American Economic Review, 93(1): 381-396.

Skiba, Paige Marta and Jeremy Tobacman. 2008. “Do Payday Loans Cause Bankruptcy?” Working Paper.

Souleles, Nicholas S. 1999. "The Response of Household Consumption to Income Tax Refunds." American Economic Review, 89(): 947-958. 